\title{
Original paper \\ Geochemistry of Mn-bearing rocks hosted in rhyolites from Hadjer Bigli (SE Lake Chad, Cameroon Line): preliminary results
}

\author{
Gbambié Isaac Bertrand MBOWOU1, Nilson Francisquini BOTELHO², Ismaïla NGOUNOUNO \\ ${ }^{1}$ School of Geology and Mining Engineering, University of Ngaoundere, P.O. Box: 115 Meiganga, Cameroon; mbowou2000@yahoo.fr \\ ${ }^{2}$ Geosciences Institute, University of Brasilia (UnB), Asa Norte, Brasilia, DF, CEP 70910-900 Brazil \\ * Corresponding author
}

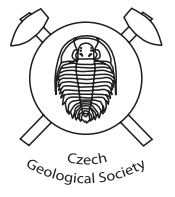

\begin{abstract}
Manganese-bearing rocks consisting of anhedral Mn- and Fe-oxyhydroxides (cryptomelane, goethite), kaolinite, tiny cerianite and zircon grains $(<10 \mu \mathrm{m})$, and euhedral to subeuhedral quartz crystals, are hosted within rhyolitic rocks of Hadjer Bigli volcano (SE Lake Chad). Their Ce (1328 ppm) and Zn (1563 ppm) contents are increased, with high $\sum$ REE values (1573 ppm).The Mn-rich rocks have been shown to be one of the most important environments for adsorption of some trace elements. The high $\mathrm{Zn}$ contents are considered to be the result of water-rock chemical reactions at intermediate to high temperatures. The sedimentary processes led likely to the concentration of manganese in the Lake Chad water and beneath, well before the volcanic activity. According to mineral chemistry and the whole-rock data, rhyolitic magma interacted with the near-surface manganese formations already concentrated by sedimentary processes.
\end{abstract}

Keywords: manganese, trace elements, Hadjer Bigli, Lake Chad, Cameroon Line

Received: March 30, 2015; accepted: August 5, 2015; handling editor: M. Štemprok

\section{Introduction}

Manganese deposits can be formed by hydrothermal, sedimentary, and supergene processes in various environments (e.g. lakes, internal seas, archipelagos, shallow marine, deep marine, as well as terrestrial). Deposits of various size, grade and origin, host oxidic manganese ores (El-Hasan et al. 2008). However, more than $95 \%$ of all deposits exploited today are of sedimentary genesis, having originated from ancient ocean water. Manganese is generally intimately associated with iron. Both are redox-sensitive elements with weakly oxidized ionic species $\left(\mathrm{Fe}^{2+}, \mathrm{Mn}^{2+}\right)$ that are fairly soluble in water in surface environments under oxygen-deficient (anaerobic) conditions. In contrast, they are both oxidized to poorly soluble $\mathrm{Fe}^{3+}$ and $\mathrm{Mn}^{4+}$ in aerobic environments.

Various trace elements can be associated with iron and manganese deposits. Thus, the distribution of trace elements can be used for monitoring of the geochemical processes that contributed to the genesis of the manganese deposits. The REE mobility for example, is controlled mainly by the redox potential of the environment. Therefore the REE patterns can be used in tracing the post-depositional processes (i.e. diagenesis) (De Carlo 1991). Polgári and Gutzmer (2012 and references therein) demonstrated the particular difficulties associated with identifying the exact genetic history of stratabound manganese deposits.

Manganese-bearing rocks discovered in the Hadjer Bigli volcano (SE of the Lake Chad) are hosted by Late
Cretaceous rhyolitic rocks. In many places, these bodies display tectonic control and rock-association that permit their correlation to deposits generated in continental basin.

Lake Chad is located in central Africa, to the North of the Congo Craton and to the East of the West African Craton. The rhyolites from Hadjer Bigli and those from Hadjer el Hamis and Hadjer al Hider (formerly named Hadjer Hider) occur at the northernmost termination of the Cameroon Line (Mbowou et al. 2012), which is an active intraplate tectonomagmatic zone, with associated alkaline volcanism, developed on both oceanic and continental lithosphere. Oriented $\mathrm{N} 30^{\circ} \mathrm{E}$, it crosses the Gulf of Guinea and Cameroon for more than $2000 \mathrm{~km}$, from Pagalu Island to Lake Chad (Vicat et al. 2002; Déruelle et al. 2007). According to Vicat et al. (2002), these rhyolites can be related to a tectonomagmatic stage of the western central Africa rift system.

The economically most valuable manganese deposits are associated with ancient and recent weathering crusts (retrograde diagenesis zone), primarily in the near equatorial areas of South America, Africa, Australia, and India. Therefore, these regions are most promising for the discovery of new high-grade manganese ore deposits (Kuleshov 2011 and references therein).

The aim of this study is to present the first mineral chemistry of the Mn-bearing rocks from the SE Lake Chad and their geochemical data, in order to identify the genetic processes which led to the high concentration of some trace elements. 


\section{Geological setting}

The Lake Chad area is mainly characterized by the occurrence of sedimentary units and volcanic outcrops. The geology of the South-east (SE) of the Lake Chad is composed of Quaternary-to-recent sandy-clay and sand units, of aeolian and fluvio-lacustrine origin. These units cover the oldest sedimentary formations and surround the rhyolitic domes and necks. Three volcanoes (Fig. 1): Hadjer el Hamis (418 m a.s.1.); Hadjer Bigli (308 m a.s.l.) and Hadjer Hidjer (283 m a.s.l.), with particular rhyolitic compositions (pantellerite and comendite) are located to the SE of Lake Chad (Mbowou et al. 2012).

The eruption of the rhyolitic rocks in this domain has likely triggered the uplifting of the Precambrian basement as evidenced by the positive isostatic gravity anomalies (from 0 to $+20 \mathrm{mGal}$ ), which are explained by the local presence of near surface heavy material over the asthenosphere (Louis 1970). Cenozoic to Quaternary sedimentary formations hide the Precambrian basement and the extensions of the tectonic evolution. In Chad, the Precambrian basement outcrops in five distinct massifs: the Mayo Kebbi Massif in the southwest, the Tibesti Massif in the north, the Ouaddaï Massif in the east, the Guera Massif in the center and the Yade Massif in the south (Isseini et al. 2012).

The discovery of the Mn-rich rocks in the volcanic outcrops of Hadjer Bigli is of special interest regarding the mineral exploration and the geodynamic significance of the SE Lake Chad domain. It may provide some insights into the petrological processes which led to their genesis. The Mn-rich rocks are hosted in the rhyolites from the Hadjer Bigli volcano (Fig. 2), where rhyolites are mined actually in an open quarry. Manganese mineralization had been previously discovered in the Goz Beida area located to the south of the Ouaddaï Massif (East of Chad). It consists of gneiss, migmatite, granitoids, quartzites, micaschists and amphibolites. A manganese hydroxide layer $0.2-0.3 \mathrm{~m}$

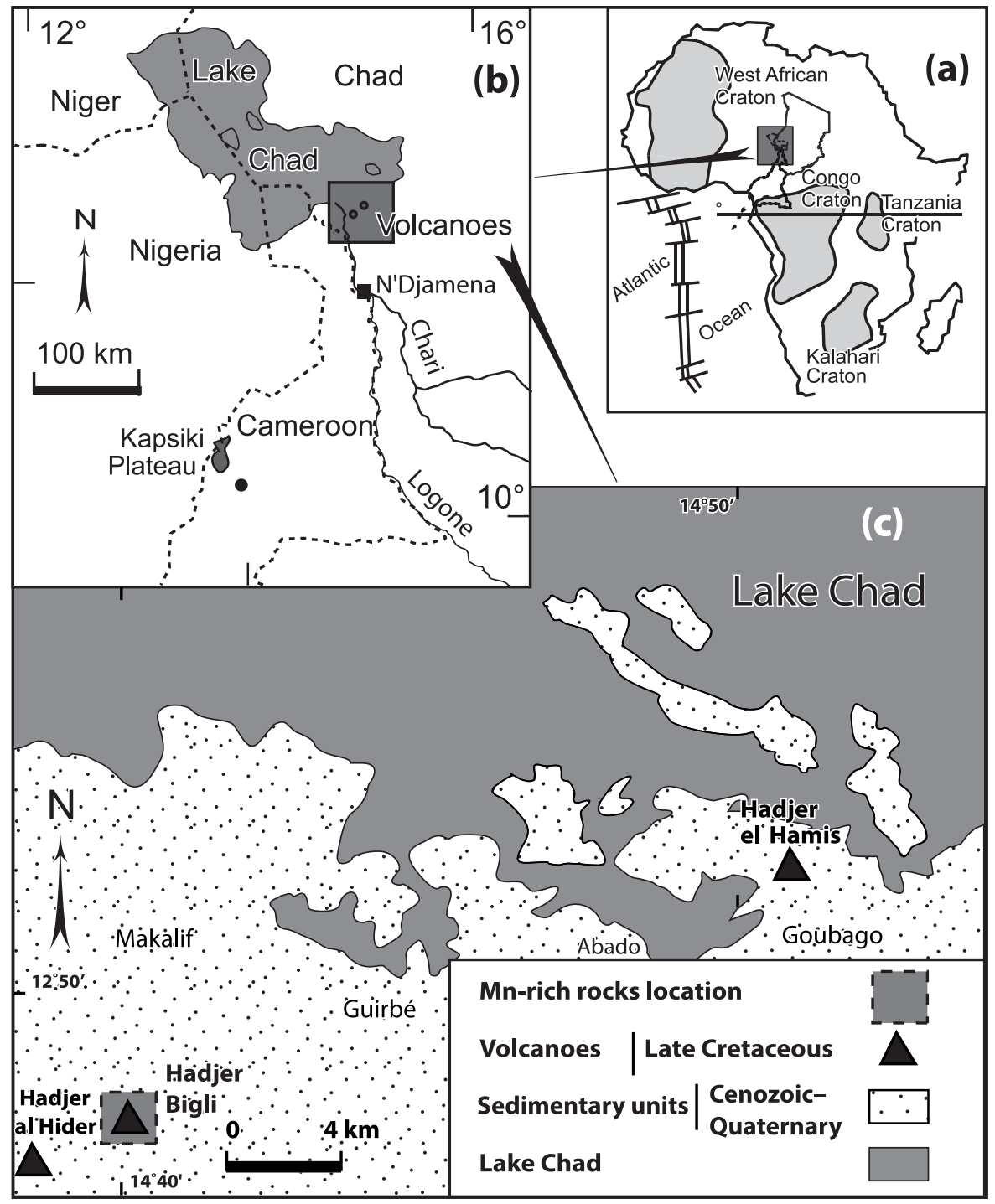

thick has been described in the Goz Beida area, with a strike length of $50 \mathrm{~m}$ (Kasser 1995). Moreover, Vicat et al (2000) had analyzed at the University of Nancy (CRPG, France) two $\mathrm{Mn}$ - and $\mathrm{Zn}$-rich clays, sampled around of N'Djamena in the Lake Chad Basin.

The geological setting of the Mn-bearing rocks from the SE Lake Chad is characterized by the dominance of the sedimentary rocks which were intruded by volcanic rocks. The main body of Hadjer Bigli plug (308 $\mathrm{m}$ a.s.1) is made up of weathered reddish brown rhyolite, which is cut by greenish dark rhyolitic dykes with a thickness of 1 to $3 \mathrm{~m}$, and by dark Mn-rich rocks. This volcanic plug of $c .15-20 \mathrm{~m}$ height is slightly flattened on its top and bordered by moderated to steep slope flanks. The blocks of rhyolites of all sizes are mainly accumulated on the flanks and in the open

Fig. 1 Location of the Lake Chad (Central Africa), the Atlantic Ocean and African Cratons (a). The sector of the Kapsiki Plateau (Northern Cameroon) is indicated (b) and the position of the Mn-rich rock occurrence (c) SE of the Lake Chad (Mbowou et al. 2012). 


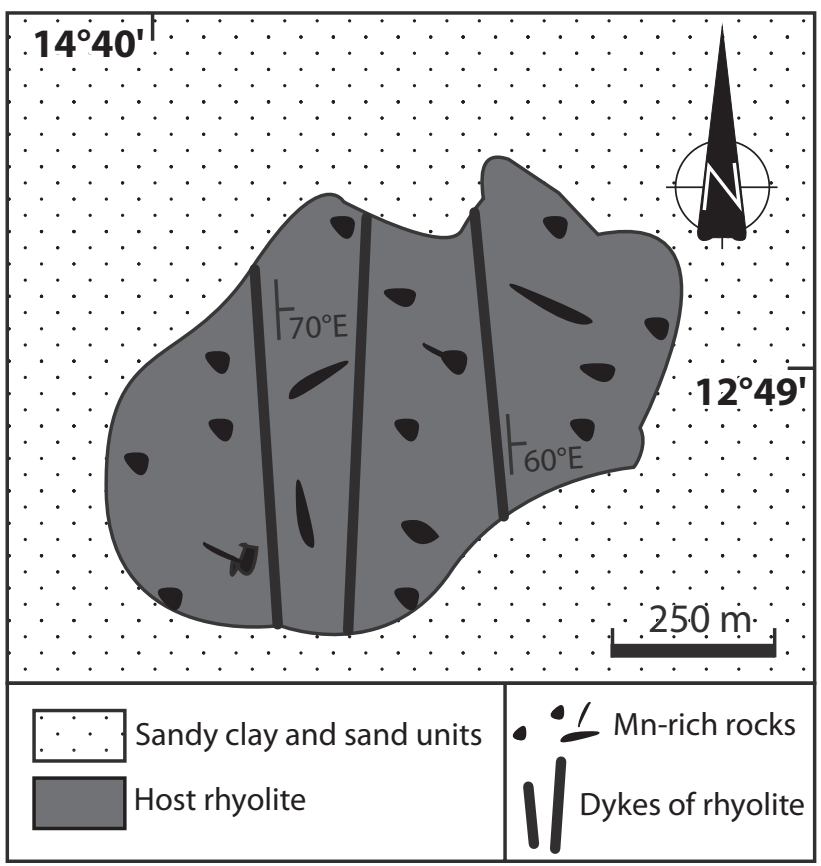

Fig. 2 Geological sketch of Hadjer Bigli volcano.

quarry. The greenish dark rhyolitic dykes (1-1.8 m thick) are subvertical (dipping $60-70^{\circ} \mathrm{E}$ ) and oriented N-S (Ganwa et al. 2009). Their distribution (trend, dip, thickness and number) may have been controlled by the regional extensional stress field (Déruelle et al. 2007). The Mn-rich rocks form sparse (5-8 vol. $\%$ ), elongated, fusiform and amoebic bodies within the rhyolite of the Hadjer Bigli volcano, with variable thicknesses up to $2 \mathrm{~m}$.

\section{Sampling and analytical methods}

The Mn-bearing rocks were sampled on rocky slopes and/or in working quarries at the Hadjer Bigli volcano. These samples were separated from rhyolite blocks with the hammer. The petrography of samples was studied by optical microscopy using an Olympus BX60 binocular microscope at the Instituto de Geociências, Universidade de Brasília (Brazil).

The JEOL JXA-8230 superprobe Electron Probe Microanalyser of the same University was used for back-scattered electron (BSE) images, qualitative and quantitative analyses of mineral phases (cryptomelane, kaolinite, goethite, zircon and cerianite). The operating conditions included an accelerating voltage of $15 \mathrm{kV}$ and a probe current of $1.08 \times 10^{-8} \mathrm{~A}$. The counting times at the peaks were $20 \mathrm{~s}$ for the all elements. The diameter of the electron beam was $10 \mu \mathrm{m}$. All data were corrected with standard ZAF correction procedures. Natural minerals and synthetic glasses were used as standards. The $\mathrm{OH}$ contents for each mineral have been estimated according to the ZAF program by deduction from the calibrated and calculated element proportions.

Whole-rock samples were crushed to fine powder in a mill equipped with two agate jars at the Instituto de Geociências, Universidade de Brasilia. Representative whole-rock major- and trace-element analyses were carried out using ICP-ES and ICP-MS methods, respectively, at the Acme Analytical Laboratories. Total loss on ignition (L.O.I), total carbon and sulfur were determined gravimetrically after heating or sintering at $1000^{\circ} \mathrm{C}$.

Lithium borate fusion and dilute acid digestion of a $0.2 \mathrm{~g}$ sample powder were employed to ensure the correct analyses of the rare earths and refractory elements. Detection limits (DL) were less than 0.05 wt. \% for the major elements, $5 \mathrm{ppm}$ for $\mathrm{Ba}$ and less than $0.6 \mathrm{ppm}$ for the REE and the other trace elements. The analyses of total carbon and sulfur were performed by gravimetric methods at the low analytical detection limits $(0.02 \mathrm{wt}$ \% $\%)$.

\section{Results}

\subsection{Petrography and mineral chemistry}

\subsubsection{Host rhyolites}

The host rhyolites are reddish brown (Fig. 3) with partly welded tuff appearance, characterized by the occurrence of scarce small vesicles $(\leq 0.5 \mathrm{~cm}$ across $)$. The rock consists of quartz, alkali feldspar (nearly pure sanidine $\mathrm{Or}_{92-95}$; Tab. 1), Fe-Ti oxide and oxyhydroxide phenocrysts (with $\mathrm{FeO}$ and $\mathrm{OH}$ contents reaching 87.3 wt. \% and 17.4 wt. \%, respectively; Tab. 2) set in an altered devitrified glassy groundmass.

In thin section, they are characterized by a strongly developed, micropoikilitic texture along with more or less

Tab. 1 Selected analyses of K-feldspar of the host rhyolite (D3, D5)

\begin{tabular}{lrrrr}
\hline Sample & \multicolumn{1}{c}{ D3 } & \multicolumn{1}{c}{ D3 } & \multicolumn{1}{c}{ D5 } & \multicolumn{1}{c}{ D5 } \\
\hline $\mathbf{S i O}_{2}$ (wt. \%) & 61.39 & 66.59 & 63.86 & 64.16 \\
$\mathbf{T i O}_{2}$ & 0.00 & 0.00 & 0.02 & 0.00 \\
$\mathbf{A l}_{2} \mathbf{O}_{3}$ & 19.90 & 15.80 & 18.88 & 18.80 \\
$\mathbf{F e O}$ & 1.61 & 3.35 & 0.86 & 0.80 \\
$\mathbf{M n O}$ & 0.02 & 0.06 & 0.01 & 0.01 \\
$\mathbf{M g O}$ & 0.01 & 0.01 & 0.00 & 0.01 \\
$\mathbf{C a O}$ & 0.01 & 0.01 & 0.03 & 0.02 \\
$\mathbf{N a}_{2} \mathbf{O}$ & 0.49 & 0.46 & 0.82 & 0.50 \\
$\mathbf{K}_{2} \mathbf{O}$ & 15.92 & 13.10 & 15.27 & 15.55 \\
$\mathbf{S r O}$ & 0.07 & 0.00 & 0.08 & 0.06 \\
BaO & 0.00 & 0.03 & 0.00 & 0.00 \\
\hline Total & 99.43 & 99.42 & 99.83 & 99.90 \\
\hline Or (mol. \%) & 95.42 & 94.87 & 92.28 & 95.18 \\
$\mathbf{A b}$ & 4.71 & 5.04 & 7.81 & 4.87 \\
An & 0.06 & 0.09 & 0.13 & 0.11 \\
\hline
\end{tabular}



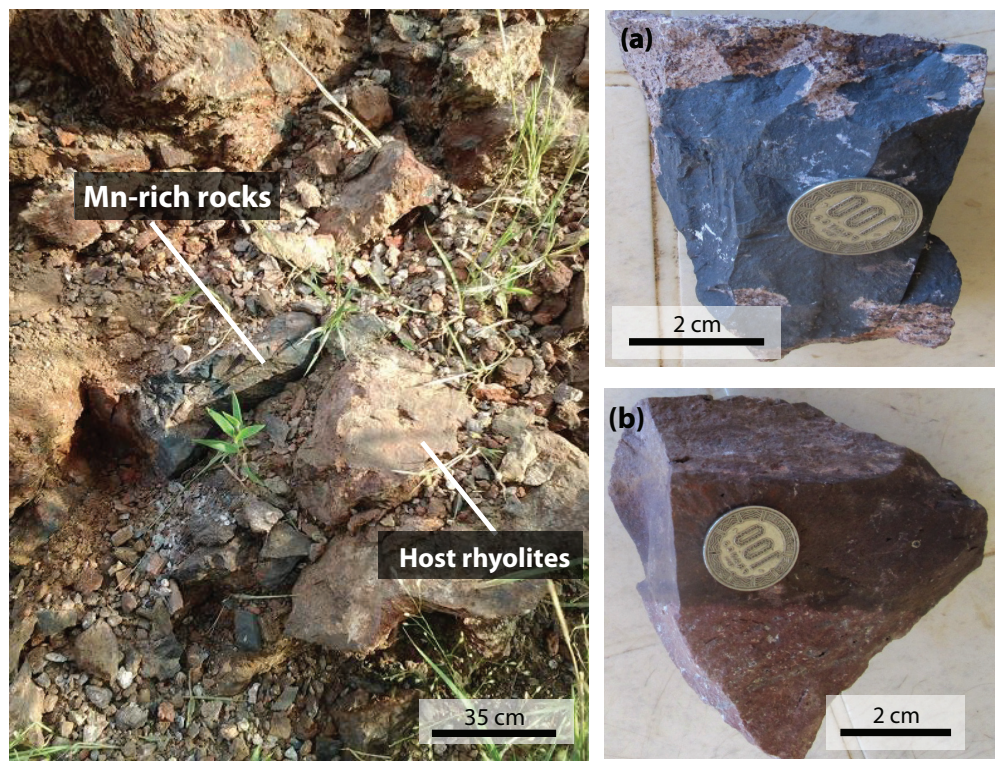

Fig. 3 Photographs of the studied Mn-rich rocks (a) and host rhyolites (b).
Tab. 2 Selected compositions of hydroxides of the host rhyolite

\begin{tabular}{lrrrr}
\hline Sample & D3 & D3 & D5 & D5 \\
\hline $\mathbf{S i O}_{2}$ (wt. \%) & 4.00 & 5.86 & 0.36 & 1.02 \\
$\mathbf{T i O}_{2}$ & 0.42 & 0.00 & 3.06 & 3.22 \\
$\mathbf{A l}_{2} \mathbf{O}_{3}$ & 1.79 & 0.45 & 0.77 & 0.94 \\
$\mathbf{F e O}$ & 84.25 & 75.33 & 87.33 & 85.52 \\
$\mathbf{M n O}$ & 0.02 & 0.33 & 0.03 & 0.07 \\
$\mathbf{M g O}$ & 0.00 & 0.05 & 0.00 & 0.01 \\
$\mathbf{C a O}$ & 0.00 & 0.14 & 0.01 & 0.00 \\
(OH) & 9.19 & 17.38 & 8.05 & 8.89 \\
\hline Total & 99.67 & 99.54 & 99.60 & 99.67 \\
\hline
\end{tabular}

rounded and partially resorbed quartz phenocrysts (up to $4 \mathrm{~mm}$ ). Some sections display micrographic texture, probably characteristic of the simultaneous crystallization of quartz and alkali feldspar from the silicic magma. Other samples contain elongated greenish dark clinopyroxene and amphibole microlites scattered throughout the groundmass and frequently in the interstices of the aggregated phenocrysts of feldspar or in gulfs of the corroded quartz. These mafic microlites are sometimes pseudomorphosed by fine-grained $\mathrm{Fe}-\mathrm{Ti}$ oxides.

\subsubsection{Mn-bearing rocks}

The Mn-bearing rocks are compact, dark grey (Fig. 3) and consist of anhedral $\mathrm{Mn}$ - and Fe-oxyhydroxides (cryptomelane, goethite), kaolinite and euhedral to subhedral quartz crystals. These rocks contain cryptomelane crystals as the most abundant mineral with high $\mathrm{MnO}$ contents (up to $79.1 \mathrm{wt}$ \%; Tab. 3) and relatively high $\mathrm{K}_{2} \mathrm{O}$ contents (up to 5.6 wt. \%). Elevated $\mathrm{SiO}_{2}$ and $\mathrm{Al}_{2} \mathrm{O}_{3}$ contents are possibly related to the presence of quartz and kaolinite crystals in the groundmass or may be attributed to an admixture of amorphous $\mathrm{SiO}_{2}$, and $\mathrm{Al}(\mathrm{OH})_{3}$ phases. Goethite (Tab. 4) contains up to 80.7 wt. \% FeO and less than 2.1 wt. $\% \mathrm{MnO}$. The amount of $\mathrm{OH}$ is estimated at 8.3 to 9.6 wt. \%. Admixture of $\mathrm{Si}$ and $\mathrm{Al}$ is low $(<5.9$ wt. $\% \mathrm{SiO}_{2}$ and $<2.7$ wt. $\% \mathrm{Al}_{2} \mathrm{O}_{3}$ ). The kaolinite (Tab. 5) displays relatively high $\mathrm{FeO}$ content (up to 5.2 wt. \%). The tiny phases unevenly distributed in the groundmass were identified according to their characteristic EDS spectra (Fig. 4), as cerianite (high Ce contents) and zircon (high $\mathrm{Zr}$ contents). These phases are heterogeneous and very small $(<10 \mu \mathrm{m})$ to be analyzed quantitatively.

Tab. 3 Selected compositions of cryptomelane crystals of the Mn-bearing rock (D2) from the SE Lake Chad

\begin{tabular}{lrrrrrrrrrr}
\hline Sample & \multicolumn{1}{c}{ D2 } & \multicolumn{1}{c}{ D2 } & \multicolumn{1}{c}{ D2 } & \multicolumn{1}{c}{ D2 } & \multicolumn{1}{c}{ D2 } & \multicolumn{1}{c}{ D2 } & \multicolumn{1}{c}{ D2 } & \multicolumn{1}{c}{ D2 } & \multicolumn{1}{c}{ D2 } & \multicolumn{1}{c}{ D2 } \\
\hline $\mathbf{S i O}_{2}$ (wt. \%) & 0.20 & 0.18 & 0.21 & 0.19 & 0.30 & 2.07 & 0.33 & 0.21 & 0.26 & 0.28 \\
$\mathbf{A l}_{2} \mathbf{O}_{3}$ & 0.89 & 0.82 & 1.09 & 1.10 & 1.15 & 1.80 & 1.46 & 1.12 & 1.16 & 0.70 \\
$\mathbf{F e O}$ & 0.38 & 0.25 & 0.20 & 0.50 & 0.44 & 0.47 & 0.84 & 0.73 & 0.87 & 0.49 \\
$\mathbf{M n O}$ & 78.58 & 78.36 & 79.16 & 79.31 & 78.60 & 76.76 & 78.12 & 79.01 & 77.97 & 78.25 \\
$\mathbf{M g O}$ & 0.00 & 0.03 & 0.00 & 0.00 & 0.00 & 0.01 & 0.00 & 0.00 & 0.00 & 0.00 \\
$\mathbf{C a O}$ & 0.11 & 0.07 & 0.06 & 0.07 & 0.02 & 0.04 & 0.05 & 0.07 & 0.10 & 0.04 \\
$\mathbf{B a O}$ & 0.09 & 0.14 & 0.19 & 0.17 & 0.03 & 0.08 & 0.01 & 0.05 & 0.00 & 0.46 \\
$\mathbf{N a}_{2} \mathbf{O}$ & 0.24 & 0.24 & 0.20 & 0.26 & 0.22 & 0.19 & 0.18 & 0.24 & 0.26 & 0.20 \\
$\mathbf{K}_{\mathbf{2}}$ & 5.12 & 5.58 & 5.29 & 5.29 & 5.07 & 4.76 & 5.35 & 4.61 & 4.43 & 5.04 \\
$(\mathbf{O H})$ & 14.39 & 14.34 & 13.50 & 12.93 & 14.08 & 13.83 & 13.62 & 13.89 & 14.79 & 14.46 \\
\hline Total & 99.99 & 100.00 & 99.91 & 99.83 & 99.90 & 100.00 & 99.95 & 99.92 & 99.84 & 99.92 \\
\hline
\end{tabular}


Tab. 4 Selected compositions of goethite crystals of the Mn-bearing rock from the SE of the Lake Chad

\begin{tabular}{lcc}
\hline Sample & D2 & D2 \\
\hline $\mathrm{SiO}_{2}$ (wt. \%) & 2.43 & 5.94 \\
$\mathrm{TiO}_{2}$ & 4.14 & 2.09 \\
$\mathrm{Al}_{2} \mathbf{O}_{3}$ & 0.87 & 2.68 \\
$\mathbf{F e O}$ & 80.70 & 77.48 \\
$\mathrm{MnO}$ & 1.55 & 2.06 \\
$\mathrm{MgO}$ & 0.02 & 0.04 \\
$\mathbf{C a O}$ & 0.10 & 0.24 \\
$\mathbf{K}_{2} \mathbf{O}$ & 0.05 & 0.09 \\
$(\mathbf{O H})$ & 9.55 & 8.31 \\
\hline Total & 99.41 & 98.92 \\
\hline
\end{tabular}

while the $\mathrm{SiO}_{2}$ content is decreased compared to the both rhyolites (48.3 wt. \%). Of the trace elements studied, the Mn-bearing rock is enriched in Ce (1329 ppm) and Zn (1563 ppm), with high $\sum$ REE value of 1573 ppm. In addition, $\mathrm{Ba}, \mathrm{Tl}, \mathrm{Mo}, \mathrm{Cd}$ and Co contents (751 ppm, 6.6 ppm, 32.9 ppm, 27.8 ppm and $9.2 \mathrm{ppm}$, respectively) are higher than in the host rhyolites. The $\mathrm{Zr}$ content of Mnrich rocks is slightly lower (1125 ppm) than in the host rhyolites (1515 and $1734 \mathrm{ppm})$. The Mn-rich rock shows a marked positive $\mathrm{Ce}$ anomaly, with a $\mathrm{Ce} / \mathrm{Ce} *$ ratio $(\mathrm{Ce} /$ $\left.\mathrm{Ce}^{*}=\mathrm{Ce}_{\mathrm{N}} / \sqrt{ }\left[\mathrm{La}_{\mathrm{N}} \times \mathrm{Pr}_{\mathrm{N}}\right]\right)$ of 8.78 and a moderate negative $\mathrm{Eu}$ anomaly similar to that of the host rhyolite (Fig. 5). The $(\mathrm{La} / \mathrm{Yb})_{\mathrm{N}}$ ratio is 5.5 .

\subsection{Whole-rock geochemistry}

Major- and trace-element compositions for the studied rocks are presented in Tab. 6.

\subsubsection{Host rhyolite}

The host rhyolites are characterized by high $\mathrm{Fe}_{2} \mathrm{O}_{3} \mathrm{t}(10.8-14.0$ wt. \%), Rb (149 and 164 ppm), and $\operatorname{Zr}$ (1515 and $1734 \mathrm{ppm})$ and low $\mathrm{MnO}$ contents (0.05 and 0.06 wt. \%). Other elements are as follows: $\mathrm{Sr}$ (4-10 ppm), Ba (40-64 ppm), Zn (140-147 ppm), Ce (185-350 ppm), Mo ( $\leq 2.5 \mathrm{ppm})$, Co (0.4-0.9 ppm), $\mathrm{Cd}(0.1-0.8 \mathrm{ppm})$ and $\mathrm{Tl}(\leq 0.1$ $\mathrm{ppm}$ ). The primitive mantle (McDonough and Sun 1995) normalized REE patterns (Fig. 5) show moderate negative Eu anomaly, with $\mathrm{Eu} / \mathrm{Eu}^{*}$ ratio $(\mathrm{Eu} /$ $\left.\mathrm{Eu}^{*}=\mathrm{Eu}_{\mathrm{N}} / \sqrt{ }\left[\mathrm{Sm}_{\mathrm{N}} \times \mathrm{Gd}_{\mathrm{N}}\right]\right)$ greater than 0.5 . Overall, the rhyolites exhibit enrichment in LREE and display slightly fractionated REE patterns with $(\mathrm{La} / \mathrm{Yb})_{\mathrm{N}}$ ratios ranging from 3.1 to 9.3 .

\subsubsection{Mn-rich rock}

The only Mn-rich rock sample contains 25.6 wt. $\%$ of $\mathrm{MnO}$,

Fig. 4 EDS spectra showing the compositions of the small Ce-bearing (Cer) (a) and Zr-bearing (b) minerals from the SE Lake Chad.

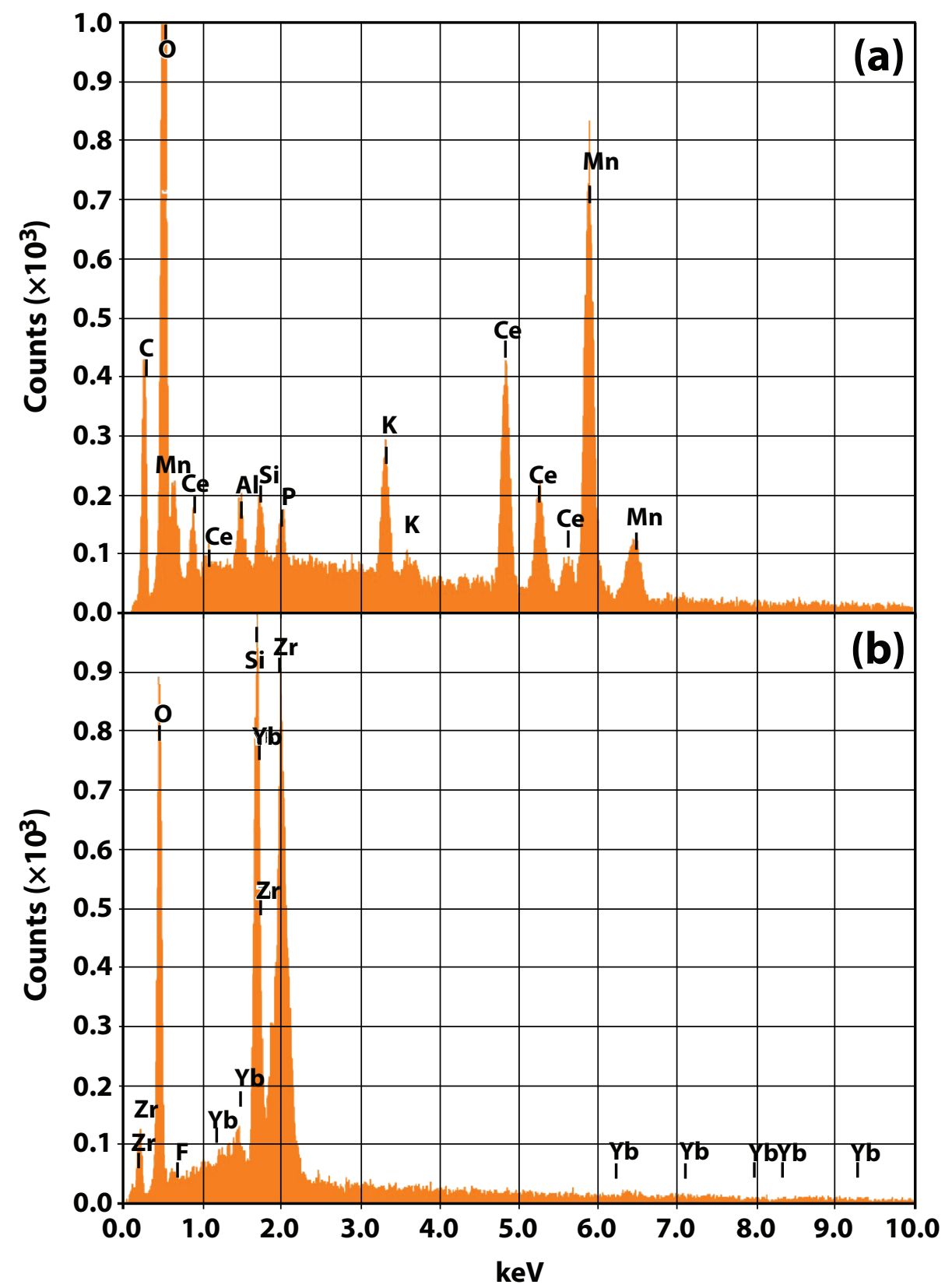


Tab. 5 Selected compositions of kaolinite crystals of the Mn-bearing rock from the SE Lake Chad

\begin{tabular}{lrrrrrr}
\hline Sample & \multicolumn{1}{c}{ D2 } & \multicolumn{1}{c}{ D2 } & \multicolumn{1}{c}{ D2 } & \multicolumn{1}{c}{ D2 } & \multicolumn{1}{c}{ D2 } & \multicolumn{1}{c}{ D2 } \\
\hline $\mathbf{S i O}_{2}$ (wt. \%) & 45.85 & 48.32 & 48.13 & 46.49 & 46.73 & 46.73 \\
$\mathbf{A l}_{2} \mathbf{O}_{3}$ & 36.37 & 37.55 & 38.38 & 40.67 & 40.22 & 40.22 \\
$\mathbf{F e O}$ & 3.30 & 5.18 & 0.45 & 0.93 & 0.73 & 0.73 \\
$\mathbf{M n O}$ & 0.05 & 0.01 & 0.00 & 0.00 & 0.00 & 0.00 \\
$\mathbf{M g O}$ & 0.03 & 0.02 & 0.00 & 0.03 & 0.04 & 0.04 \\
$\mathbf{C a O}$ & 0.08 & 0.05 & 0.05 & 0.05 & 0.07 & 0.07 \\
$\mathbf{N a}_{2} \mathbf{O}$ & 0.05 & 0.04 & 0.04 & 0.02 & 0.05 & 0.05 \\
$\mathbf{K}_{2} \mathbf{O}$ & 0.08 & 0.14 & 0.04 & 0.62 & 0.33 & 0.33 \\
$(\mathbf{O H})$ & 14.03 & 8.46 & 12.70 & 11.16 & 11.82 & 11.82 \\
\hline Total & 99.84 & 99.77 & 99.79 & 99.98 & 99.98 & 99.98 \\
\hline
\end{tabular}

\section{Discussion}

\subsection{Genetic types of manganese rocks and ores}

In general, four main genetic types of manganese rocks and ores were defined (Kuleshov 2011 and references therein): (1) sedimentary (sedimentary s.s. and volcanosedimentary), (2) magmatogenic (hydrothermal and contact-metasomatic), (3) metamorphogenic (related to regional and contact metamorphism of sedimentary and magmatogenic ore accumulations) and (4) continentalcrust weathering-related (residual, infiltrational, and karst cavern filling).

Most manganese rocks and ores are primarily sedimentary formations, formed in sedimentary basins. The majority of deposits mined at present in South America, Africa, Australia, and other regions are confined to supergene lateritic weathering of Mn-rich source rocks in the equatorial-tropical zone.

\subsection{Conditions for the concentration of elements}

The relatively low $\mathrm{SiO}_{2}$ contents (48.3 wt. \%) and the presence of euhedral to subhedral quartz of magmatic origin in the Mn-bearing rocks from Lake Chad is explained as an evidence of an combined effect of the early continental Mn-rich sedimentary deposits (see Louis 1970) and intrusion of a rhyolite hosting a hydrothermal system. High Ce content and marked positive Ce anomaly in Mn-rich rocks from Hadjer Bigli may have resulted from cerianite $\left(\mathrm{CeO}_{2}\right)$ precipitation controlled by the local Eh-pH conditions (Braun et al. 1990, 1998) or oxidation scavenging (adsorption) of $\mathrm{Ce}(\mathrm{IV})$ on the Mn- and Fe-oxyhydroxides (Ohta and Kawabe 2001). According to Mongelli et al. (2013), Mn-oxyhydroxides may play a significant role in promoting Ce oxidation, especially given that the $\mathrm{Ce}$ (III) to $\mathrm{Ce}(\mathrm{IV})$ transition is often coupled with the reduction of $\mathrm{Mn}$ (IV) to $\mathrm{Mn}$ (III) or Mn(II) (Ohta and Kawabe 2001). In addition, according to Laveuf and Cornu (2009), Mn-oxyhydroxides have a higher REE sorption capacity than Fe-oxyhydroxides at the $\mathrm{pH}$ conditions typically found in soils.

The development of positive Ce anomaly of the Mnbearing rocks from the SE Lake Chad was thus likely linked to the oxidation of $\mathrm{Ce}(\mathrm{III})$ to $\mathrm{Ce}(\mathrm{IV})$, leading to the precipitation of cerianite, coupled with the reduction of $\mathrm{Mn}(\mathrm{IV})$ to $\mathrm{Mn}(\mathrm{III})$. This oxidative scavenging is a three-stage process, comprising (1) initial sorption of trivalent REE onto Mn-oxyhydroxides, followed by (2) oxidation of $\mathrm{Ce}$ by surface catalysis on Mn-hydroxides (Koeppenkastrop and De Carlo 1992; Ohta and Kawabe

Tab. 6 Whole-rock major- (wt. \%) and trace-element (ppm) analyses of a Mn-bearing rock (D2) and the two host rhyolites (D3, D5)

\begin{tabular}{|c|c|c|c|c|c|c|c|c|c|c|c|c|c|c|}
\hline & $\mathrm{SiO}_{2}$ & $\mathrm{TiO}_{2}$ & $\mathrm{Al}_{2} \mathrm{O}_{3}$ & $\mathrm{Fe}_{2} \mathrm{O}_{3} \mathrm{t}$ & $\mathrm{MnO}$ & MgO & $\mathrm{CaO}$ & $\mathrm{Na}_{2} \mathrm{O}$ & $\mathrm{K}_{2} \mathrm{O}$ & $\mathbf{P}_{2} \mathbf{O}_{5}$ & L.O.I & Total/C & Total/S & Total \\
\hline D2 & 48.30 & 0.29 & 7.74 & 7.70 & 25.61 & $<0.01$ & 0.06 & 0.08 & 2.06 & 0.14 & 7.50 & $<0.02$ & $<0.02$ & 99.39 \\
\hline D3 & 71.12 & 0.19 & 7.05 & 14.01 & 0.05 & 0.03 & 0.03 & 0.14 & 4.42 & 0.04 & 2.50 & 0.02 & $<0.02$ & 99.57 \\
\hline D5 & 71.89 & 0.25 & 9.10 & 10.82 & 0.06 & $<0.01$ & 0.06 & 0.21 & 4.75 & 0.08 & 2.30 & 0.03 & $<0.02$ & 99.54 \\
\hline
\end{tabular}

\begin{tabular}{lccccccccccccccc}
\hline & Be & Rb & Cs & Ba & Sr & Ga & Sn & W & Ta & Nb & Th & U & Zr & Hf & Y \\
\hline D2 & 2 & 31.9 & 0.1 & 751 & 35.6 & 59.9 & 10 & $<0.5$ & 9.2 & 109.4 & 30.7 & 6.4 & 1125.3 & 28.5 & 103.2 \\
D3 & 8 & 149.5 & 0.4 & 64 & 10.1 & 49.1 & 17 & 2.2 & 15.1 & 171.1 & 29.0 & 7.6 & 1734.3 & 41.7 & 191.0 \\
D5 & 7 & 164.3 & 0.5 & 40 & 4.0 & 38.3 & 15 & 2.6 & 13.5 & 225.5 & 28.7 & 7.6 & 1515.8 & 35.6 & 154.7 \\
\hline
\end{tabular}

\begin{tabular}{lrrrrrrrrrrrrrcccccc}
\hline & La & Ce & Pr & Nd & Sm & Eu & Gd & Tb & Dy & Ho & Er & Tm & Yb & Lu & $\sum$ REE \\
\hline D2 & 80.9 & 1328.6 & 16.60 & 58.6 & 16.25 & 2.59 & 17.92 & 3.36 & 20.52 & 4.11 & 11.02 & 1.57 & 10.04 & 1.32 & 1573 \\
D3 & 80.5 & 185.6 & 21.37 & 84.6 & 22.15 & 5.27 & 30.61 & 5.63 & 38.27 & 7.52 & 19.79 & 2.80 & 17.58 & 2.50 & 524 \\
D5 & 180.7 & 350.5 & 39.48 & 147.9 & 29.06 & 5.04 & 30.27 & 4.88 & 30.91 & 5.50 & 15.64 & 2.12 & 13.21 & 1.89 & 857 \\
\hline
\end{tabular}

\begin{tabular}{lrrrrrrrrrrrrrrrrr}
\hline & Ni & $\mathbf{C r}$ & $\mathbf{C o}$ & $\mathbf{C u}$ & $\mathbf{C d}$ & $\mathbf{Z n}$ & $\mathbf{P b}$ & $\mathbf{M o}$ & $\mathbf{A g}$ & $\mathbf{A s}$ & $\mathbf{H g}$ & $\mathbf{T l}$ & $\mathbf{E u} / \mathbf{E u} * \mathbf{C e} / \mathbf{C e} * \mathbf{L a} / \mathbf{Y b})_{\mathbf{N}}$ \\
\hline D2 & 0.5 & $<20$ & 9.2 & 7.8 & 27.8 & 1563 & 42.5 & 32.9 & 1.7 & 1.7 & 0.05 & 6.6 & 0.46 & 8.78 & 5.48 \\
D3 & 0.6 & 40 & 0.9 & 1.5 & 0.8 & 147 & 24.9 & 0.8 & $<0.1$ & $<0.5$ & $<0.01$ & $<0.1$ & 0.61 & 1.08 & 3.12 \\
D5 & 0.4 & 20 & 0.4 & 1.8 & 0.1 & 140 & 25.9 & 2.5 & $<0.1$ & $<0.5$ & $<0.01$ & $<0.1$ & 0.52 & 1.01 & 9.31 \\
\hline
\end{tabular}


2001), and (3) preferential desorption of trivalent REEs, including Ce(III) not transformed to Ce(IV).

Various mechanisms may cause local precipitation of metals (such as $\mathrm{Ba}, \mathrm{Tl}, \mathrm{Mo}, \mathrm{Cd}, \mathrm{Co}, \mathrm{Fe}, \mathrm{Cu}, \mathrm{Pb}$ and $\mathrm{Zn}$ ), resulting in their accumulation in metallic ore. The relatively high $\mathrm{Zn}$ contents in the Mn-rich rocks from SE Lake Chad could be considered as a result of water-rock chemical reactions. Thus, $\mathrm{Zn}$, is highly concentrated in hydrous Mn-oxides (Loganathan and Burau 1973) and thallium is firmly fixed in the lattice of Mn-oxides (e.g., cryptomelane), presumably replacing $\mathrm{K}_{2} \mathrm{O}, \mathrm{Ba}$ and $\mathrm{Pb}$.

\subsection{Genesis of Mn-bearing rocks}

Manganese is concentrated in ore deposits mostly in exogenic environments at the atmosphere-rock interface (retrograde diagenesis zone), at the sedimentary-diagenetic stage (early diagenesis). To a lesser extent, this may have taken place at subsequent stages of the initial sediment lithification and transformation of sedimentary or volcanosedimentary rocks (subsidence diagenesis, nodule formation). Primary manganese oxide ores (Kuleshov 2011) are formed under a medium with high oxidizing potential (Eh), mostly in coastal shallow waters or at the basin bottom during the submarine discharge of hydrothermal solutions. Manganese carbonates originate within sediments during the diagenesis and/or catagenesis stages due to the redistribution of $\mathrm{Mn}$ or the influx of external $\mathrm{Mn}$ into lithified sediments at the catagenesis (epigenesis) stage.

Manganiferous rocks from the SE Lake Chad probably originated from superposition of low-temperature sedimentary and higher temperature hydrothermal processes spatially related to the rhyolite volcanic center. Low-temperature hydrothermal and terrestrial weathering processes may have served as primary source of manganese accumulated in local basins. Grasselly and Ponater (1988) have measured the $\mathrm{Ce} / \mathrm{La}$ ratio $(2.5-3.2)$ in the Urkut manganese deposit of Hungary and used it as an indi-

Fig. 5 Primitive mantle-normalized (McDonough and Sun 1995) REE diagram. cator for the terrigenous source of REE. In our case, the high value of the Ce/La ratio (up to 16.4) coupled with the presence of phases such as cryptomelane, kaolinite and goethite indicates unambiguously the sedimentary origin of the manganese rocks from Hadjer Bigli (SE Lake Chad). Mobilization of $\mathrm{Mn}$ and some other elements could be triggered by the heat provided by the intrusion of the Hadjer Bigli rhyolite. Similar REE patterns for the Mn-rich rock and the host rhyolites, except the Ce anomaly, may support this idea. The presence of euhedral quartz crystals within the Mn-rich rocks is unusual for ordinary Mn-sedimentary formations. It may represent evidence either for mechanical entrainment of weathered material sourced from the host rhyolite, or for the circulation of heated hydrothermal fluids in solid rhyolite.

The Mn-rich rocks from the SE Lake Chad were probably formed by a combination of sedimentary and volcanic processes which involved fluid influx from the crystallizing rhyolitic rocks. Rhyolitic melt generated beneath the Hadjer Bigli plug had likely encountered the sedimentary Mn-rich rocks, which were generated early near the surface, during the uplift. However, the sedimentary processes led to the concentration of Mn-

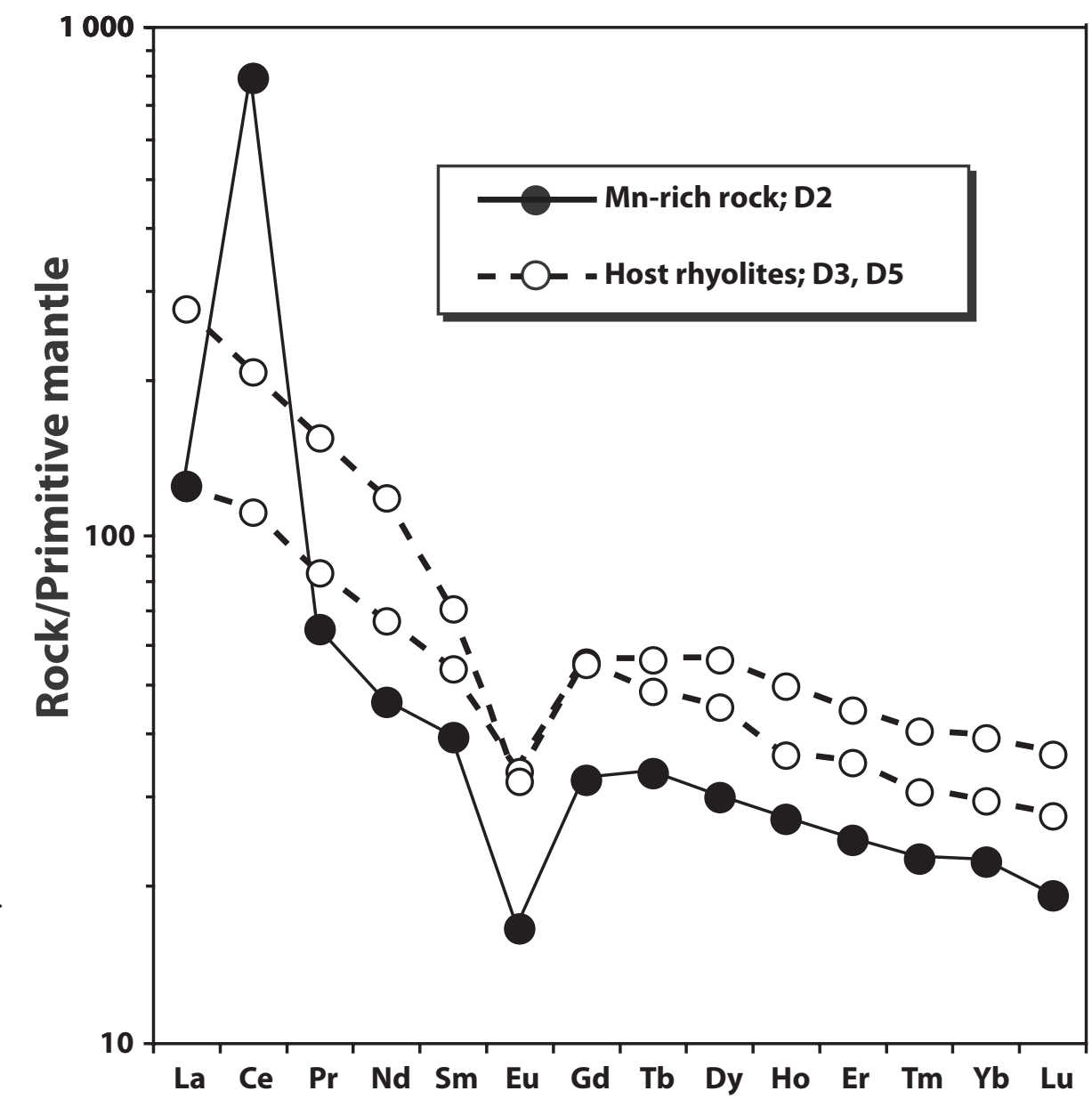


rich solutions in the lake water and beneath significantly before the volcanic activity started.

\section{Conclusions}

The Mn-bearing rocks from the SE Lake Chad consisting of quartz, cryptomelane, goethite, kaolinite, cerianite and zircon crystals hosted in reddish brown rhyolites were generated likely from a succession of sedimentary and volcanic processes. Increased concentrations of trace elements such as $\mathrm{Zn}$ and $\mathrm{Ce}$ (positive anomaly), are related to their absorption on Mn oxides. The positive Ce anomaly was likely linked to the oxidation of $\mathrm{Ce}$ (III) to $\mathrm{Ce}$ (IV) that led to the precipitation of cerianite, coupled with the reduction of $\mathrm{Mn}(\mathrm{IV})$ on the surface of Mn-oxides.

Acknowledgements. We are grateful to the TWAS (The World Academy of Sciences) organization for having provided a five-month award for research and advanced training of G.I.B.M. at the Geosciences Institute, University of Brasilia (UnB). Lagmet Claudial is acknowledged for his assistance during field-work in Lake Chad area. Milan Kohút and Jiř́ Zachariáš are thanked for their insightful comments and detailed reviews. The editorial work of Miroslav Štemprok and Vojtěch_Janoušek, which has significantly improved the quality of this manuscript, is acknowledged.

\section{References}

Braun JJ, Pagel M, Muller JP, Bilong P, Michard A, Guillet B (1990) Cerium anomalies in lateritic profiles. Geochim Cosmochim Acta 54: 781-795

Braun JJ, Viers J, Dupré B, Polve M, Ndam J, Muller JP (1998) Solid/liquid REE fractionation in the lateritic system of Goyoum, East Cameroon: the implication for the present dynamics of the soil covers of the humid tropical regions. Geochim Cosmochim Acta 62: 273-299

De CARlo EH (1991) Paleooceanographic implications of rare earth element variability within a Fe-Mn crust from central Pacific Ocean. Mar Geol 98: 449-467

Déruelle B, Ngounouno I, Demaiffe D (2007) The "Cameroon Hot Line" (CHL): a unique example of active alkaline intraplate structure in both oceanic and continental lithospheres. C R Geosci 339: 589-600

El-Hasan T, Al-Malabeh A, Komuro K (2008) Rare Earth Elements geochemistry of the Cambrian shallow marine manganese deposit at Wadi Dana, south Jordan. JJEES 1: 45-52

Ganwa AA, Doumnang MJC, Lagmet C (2009) Pétrographie et données structurales sur les dômes rhyolitiques du sud du Lac Tchad (Dandi-Hadjer El Hamis): relation avec la Ligne du Cameroun. Rev Cames 08: 80-85

Grasselly G, Ponater G (1988) Rare Earth Elements in the manganese deposit of Urkurt (Bakony Mountains, Hungary). Ore Geol Rev 4: 115-124

Isseini M, André-Mayer A-S, Vanderhaeghe O, Barbey P, Deloule E (2012) A-type granites from the Pan-African orogenic belt in south-western Chad constrained using geochemistry, $\mathrm{Sr}-\mathrm{Nd}$ isotopes and $\mathrm{U}-\mathrm{Pb}$ geochronology. Lithos 153: 39-52

KASSER MY (1995) Evolution précambrienne de la région du Mayo Kebbi (Tchad). Un segment de la Chaîne Panafricaine. Unpublished Ph.D. thesis, Muséum d'Histoire Naturelle de Paris, pp 1-217

Koeppenkastrop D, De Carlo EH (1992) Sorption of rareearth elements from seawater onto synthetic mineral particles: an experimental approach. Chem Geol 95: 251-263

Kuleshov VN (2011) Manganese deposits: communication 1. Genetic models of manganese ore formation. Lithol Min Resour 46: 473-493

Laveuf C, Cornu S (2009) A review on the potentiality of rare earth elements to trace pedogenetic processes. Geoderma 154: 1-12

LOGANATHAN P, BuRAu RG (1973) Sorption of heavy metal ions by a hydrous manganese oxide. Geochim Cosmochim Acta 37: 1277-1293

Louis P (1970) Contribution géophysique à la connaissance géologique du bassin du Lac Tchad. ORSTOM report 42: pp 1-311

Mbowou GiB, Lagmet C, Nomade S, Ngounouno I, Déruelle B, Ohnenstetter D (2012) Petrology of the Late Cretaceous peralkaline rhyolites (pantellerite, comendite) from Lake Chad, Central Africa. J Geosci 57: 127-141

McDonough WF, Sun SS (1995) The composition of the Earth. Chem Geol 120: 223-253

Mongelli G, Mameli P, Oggiano G, Sinisi R (2013) Generation of Ce anomalies in SW Sardinian Mn ores. J Geochem Explor 133: 42-49

Ohta A, Kawabe I (2001) REE(III) adsorption onto Mn dioxide $\left(\delta-\mathrm{MnO}_{2}\right)$ and $\mathrm{Fe}$ oxyhydroxide: $\mathrm{Ce}(\mathrm{III})$ oxidation by $\delta-\mathrm{MnO}_{2}$. Geochim Cosmochim Acta 65: 695-703

PolgáRi M, GutzMer J (2012) Manganese metallogenesis: introduction to the special issue. Ore Geol Rev 47: 1-4

Vicat J-P, Djoret D, Kadjangara E, Doumnang J-C (2000) Compositions chimiques des argiles de dessiccations des mares semi-permanentes de la ville de N'Djamena. Etude réalisée pour les Services Techniques de la ville de N'Djamena; Projet CAMPUS 9416400 "La nappe phréatique de la cuvette tchadienne". Preliminary report LGHG/04/00, N'Djamena pp 1-2

Vicat J-P, Pouclet A, Bellion Y, Doumnang J-C (2002) Les rhyolites hyperalcalines (pantellérites) du lac Tchad. Composition et signification tectonomagmatique. C R Geosci 334: 886-891 